\title{
Strategi Perencanaan Model Bisnis Perusahaan Jasa Konsultan Arsitektur dan Jasa Kontraktor PT Architectaria Media Cipta
}

\author{
The Strategy of Business Model Planning for Architecture Consultant and Contractor's Service \\ Company PT Architectaria Media Cipta
}

\author{
Amirullah Muh. Amin ${ }^{1 *}$, Lukman M. Baga ${ }^{2 \sharp}$, dan Netti Tinaprilla ${ }^{2 \sharp}$ \\ ${ }^{1}$ Magister Manajemen dan Bisnis, Sekolah Bisnis Institut Pertanian Bogor \\ Gedung SB IPB-Jl Raya Pajajaran, Bogor, Jawa Barat - 16151 \\ ${ }^{2}$ Departemen Agribisnis, Fakultas Ekonomi dan Manajemen, Institut Pertanian Bogor \\ Jl. Kamper, Wing 4 Level 5, Kampus IPB Dramaga Bogor, Jawa Barat 16680
}

\begin{abstract}
ABSTRAK
PT Architectaria Media Cipta adalah salah satu perusahaan didalam industri konstruksi di Indonesia. Jasa konsultan arsitektur dan jasa kontraktor adalah dua jenis produk dari perusahaan ini. Tujuan dari penelitian ini adalah untuk mengambarkan dan memperbaiki model bisnis yang dijalankan oleh PT Architectaria Media Cipta berdasarkan pendekatan Business Model Canvas (BMC) dan analisis SWOT, lalu menyusun prototipe model bisnis baru bagi PT Architectaria Media Cipta dimasa mendatang dengan menggunakan pendekatan Blue Ocean Strategy (BOS). Prosedur pengumpulan data pada penelitian ini adalah dengan wawancara terstruktur. Metodologi penelitian dengan menggunakan pendekatan Business Model Canvas (BMC), analisis SWOT, dan Blue Ocean Strategy (BOS). Hasil analisis SWOT pada sembilan unsurBusiness Model Canvas (BMC) menunjukkan bahwa terdapat faktor internal dan eksternal yang menjadi kekuatan dan kelemahan bagi perusahaan dalam menjalankan model bisnisnya. Ada tujuh unsur yang harus diperbaiki secara majordan dua unsur diperbaiki secara minor. Prototipe model bisnis baru dibuat dengan proposisi nilai baru yaitu membuat produk home and office furnishings dengan desain yang unik, ukuran yang fixed, bobot yang ringan sehingga dapat dijual secara massal melalui webstore dan marketplace. Produk inovatif dibuat dengan memanfaatkan material sisa dengan konsep re-use dan re-cycle, sehingga harga jual produk tetap murah.
\end{abstract}

Kata kunci: analisis SWOT, blue ocean strategy, business model canvas, jasa konsultan arsitektur, jasa kontraktor

\section{ABSTRACT}

PT Architectaria Media Cipta is an architectural consulting and contractor company.The purpose of this research is to describe and improve the business model used by PT Architectaria Media Cipta based on Business Model Canvas (BMC) approach and SWOT analysis, and then develop a new business model prototype for PT Architectaria Media Cipta using Blue Ocean Strategy (BOS).BMC consist of customer segments, value propositions, channels, customer relationships, revenue streams, key resources, key activities, key partnerships, and cost structures. The data collected bystructured interview.There are seven unsurts that need to be improved in a major way, and the two unsurts are remedied in a minor.The new business model prototype is created with a new value proposition that makes home and office furnishings products with unique designs, fixed size, light weight that can be sold massively through webstores and marketplace. Innovative products made by utilizing waste materials with the concept of re-use and re-cycle, therefore) the selling price of the product remains affordable.

Key words: architectural consulting services, blue ocean strategy, business model canvas, contractor services, SWOT analysis 


\section{PENDAHULUAN}

Jumlah perusahaan yang bergerak didalam industri jasa konstruksi pada tahun 2010 sampai dengan tahun 2015 mengalami peningkatan sebesar 1.871, pertumbuhan rata-rata sebesar 375 perusahaan pertahun (BPS 2016). Selanjutnya menurut data BPS (2016) juga menunjukkan terjadi peningkatan nilai proyek dibidang industri konstruksi pada periode tahun 2012-2015, untuk proyek konstruksi bangunan gedung nilai proyek sebesar 128.551.604 juta pada tahun 2012 sampai dengan 189.045.215 juta pada tahun 2015. Selanjutnya untuk proyek konstruksi bangunan sipil nilai proyek sebesar 237.019.258 juta pada tahun 2012 sampai 341.491 .328 juta pada tahun 2015. Kemudian untuk proyek konstruksi bangunan khusus nilai proyek sebesar 74.782.311 juta pada tahun 2012 sampai dengan 105.336.144 juta pada tahun 2015.

Berdasarkan data BPS (2016) tersebut, dapat dilihat bahwa jumlah dan nilai proyek konstruksi di Indonesia terus mengalami peningkatan setiap tahun. Jumlah perusahaan jasa konsultan perencana, konsultan pengawas, dan jasa kontraktor yang bergerak dalam bidang industri konstruksi terus bertambah seperti yang ditunjukkan pada Tabel 1, sehingga persaingan usaha dalam industri konstruksi menjadi lebih ketat. PT Architectaria Media Cipta (AMC) adalah salah satu perusahaan yang juga bergerak didalam industri konstruksi. Beberapa produk yang diberikan oleh perusahaan ini adalah layanan jasa konsultan (desain arsitektur, desain interior), dan jasa kontraktor.

Tingginya persaingan usaha didalam industri konstruksi membuat PT AMC perlu memiliki model bisnis yang jelas dan strategi bersaing untuk tetap dapat bertahan didalam industri konstruksi tersebut. Stategi bersaing adalah upaya yang di lakukan oleh suatu perusahaan dalam memenangkan sebuah pasar dengan cara memberikan keunggulan-keunggulan dalam bersaing, menganalisis perusahaan pesaing, serta melaksanakan strategi pemasaran yang efektif (Porter, 1992; Halim dan Mustamu, 2013). Menurut Guna-wan dan Indriyani (2014), model bisnis dan strategi-strategi diperlukan agar perusahaan dapat bersaing terutama dengan perusahaan yang lebih dahulu berdiri, dan terus berkembang didalam industri konstruksi yang semakin ketat.

Berdasarkan uraian tersebut, maka tujuan dari penelitian ini adalah (1) Mengidentifikasi model bisnis yang dijalankan oleh PT AMC saat ini dengan pendekatan sembilan unsur Business Model Canvas (BMC); (2) Mengidentifikasi apa saja faktor eksternal dan internal yang mempengaruhi model bisnis perusahaan PT AMC; (3) Merencanakan perbaikan model bisnis PT AMC dan menyusun program-program perbaikan bagi perusahaan dimasa mendatang; dan (4) Merencanakan prototipe model bisnis baru sebagai strategi pengembangan bisnis untuk PT AMC dimasa depan.

Tabel 1. Jumlah perusahaan konstruksi di indonesia dan nilai pekerjaan proyek konstruksi yang telah diselesaikan tahun 2010-2015

\begin{tabular}{ccc}
\hline Tahun & $\begin{array}{c}\text { Jumlah } \\
\text { Perusahaan } \\
\text { Konstruksi }\end{array}$ & $\begin{array}{c}\text { Nilai Pekerjaan Konstruksi } \\
\text { yang Diselesaikan (Juta } \\
\text { Rupiah) }\end{array}$ \\
\hline 2010 & 132.158 & 313.172 .994 \\
2011 & 134.004 & 376.123 .348 \\
2012 & 129.862 & 440.353 .173 \\
2013 & 131.080 & 509.025 .854 \\
2014 & 129.819 & 570.905 .169 \\
2015 & 134.029 & 635.872 .687 \\
\hline
\end{tabular}

Sumber: BPS Republik Indonesia, 2016

(https://www.bps.go.id/linkTableDinamis/view/id/912)

\section{METODE PENELITIAN}

Pengambilan data untuk penelitian ini dilakukan di kantor, design studio, workshop, dan warehouse milik PT AMC yang berada di wilayah Kodya Bogor pada bulan Januari sampai dengan Juni 2017. Data yang dibutuhkan dalam penelitian ini terdiri dari data primer data sekunder. Data primer didapatkan dari hasil wawancara, focus group discussion (FGD) dan pengisian kuesioner, data sekunder berupa dokumen-dokumen perusahaan, dan studi literatur. Pemilihan nara sumber berdasarkan purposive sampling dengan maksud contoh yang dipilih memiliki pengetahuan, keahlian, dan kompetensi dalam bidang yang dikaji pada penelitian ini. Responden terdiri atas responden internal dan eksternal. Responden internal pada penelitian ini adalah direktur, dan para manajer perusahaan. Responden eksternal adalah pelaku bisnis konstruksi, akademisi, organisasi atau asosiasi jasa konstruksi. Data yang dibutuhkan dalam penelitian ini terdiri dari data primer (hasil wawancara, FGD dan pengisian kuisioner), dan data sekunder (dokumen perusahaan, dan studi literatur). Pemilihan nara sumber berdasarkan purposive sampling dengan harapan contoh yang dipilih memiliki pengetahuan, 
keahlian, dan kompetensi dalam bidang yang dikaji pada penelitian ini.

Tahapan yang dilakukan dalam melakukan analisis dan pengolahan data didalam penelitian ini yaitu: penelitian ini diawali dengan melihat atau memotret model bisnis yang dijalankan oleh perusahaan PT Architectaria Media Cipta saat ini dengan menganalisis lingkungan dan aktivitas bisnis internal perusahaan dengan menggunakan sembilan unsur BMC. Selanjutnya dilakukan penilaian secara mendetail terhadap masing-masing unsur BMC menggunakan analisis SWOT. Tujuannya untuk mengidentifikasi faktorfaktor internal dan eksternal apa saja yang memengaruhi lingkungan model bisnis yang dijalankan oleh perusahaan PT AMC. Berdasarkan hasil penilaian atau analisis SWOT tersebut akan diketahui apa saja faktor yang menjadi isuisu strategik dalam pelaksanaan model bisnis perusahaan PT AMC. Kerangka pemikiran konseptual dari penelitian ini dapat dilihat pada Gambar 1.

\section{HASIL DAN PEMBAHASAN}

PT Architectaria Media Cipta adalah perusahaan yang menyediakan layanan jasa: (1) desain arsitektur dan turunannya seperti pembuatan desain layout bangunan, desain massa bangunan, desain arsitektur landscape, shop drawing, as built drawing, mechanical and electrical drawing; (2) desain interior dan turunannya, seperti interior design scheme, color scheme, wall treatment, window treatment, floor treatment, lighting, accoustic, furniture design, dan sebagainya; (3) jasa konstruksi yang mencakup pembangunan sarana fisik seperti rumah, bangunan kantor, pabrik, gudang atau warehouse, gedung, konstruksi landscape, dan sebagainya.

Dalam menjalankan kegiatan usahanya, PT AMC selalu berpegang kepada visi, dan misiyang telah disusun oleh manajemen perusahaan. Visi PT AMC adalah "Menjadi perusahaan jasa konsultan desain arsitektur, desain interior, dan jasa kontraktor yang dihormati, dan berkelas internasional". Misi PT AMC adalah (1) Memberikan layanan jasa konsultansi yang bermutu tinggi, sehingga menjadi perusahaan konsultan arsitek, desain interior, dan jasa kontraktor yang unggul di pasar nasional dan global; (2) Menghasilkan desain bermutu tinggi dan memberikan layanan kepada klien dengan prinsip kejujuran dan integritas; (3) Menjadikan mutu layanan jasa dan standar kerja sebagai tulang punggung perusahaan.

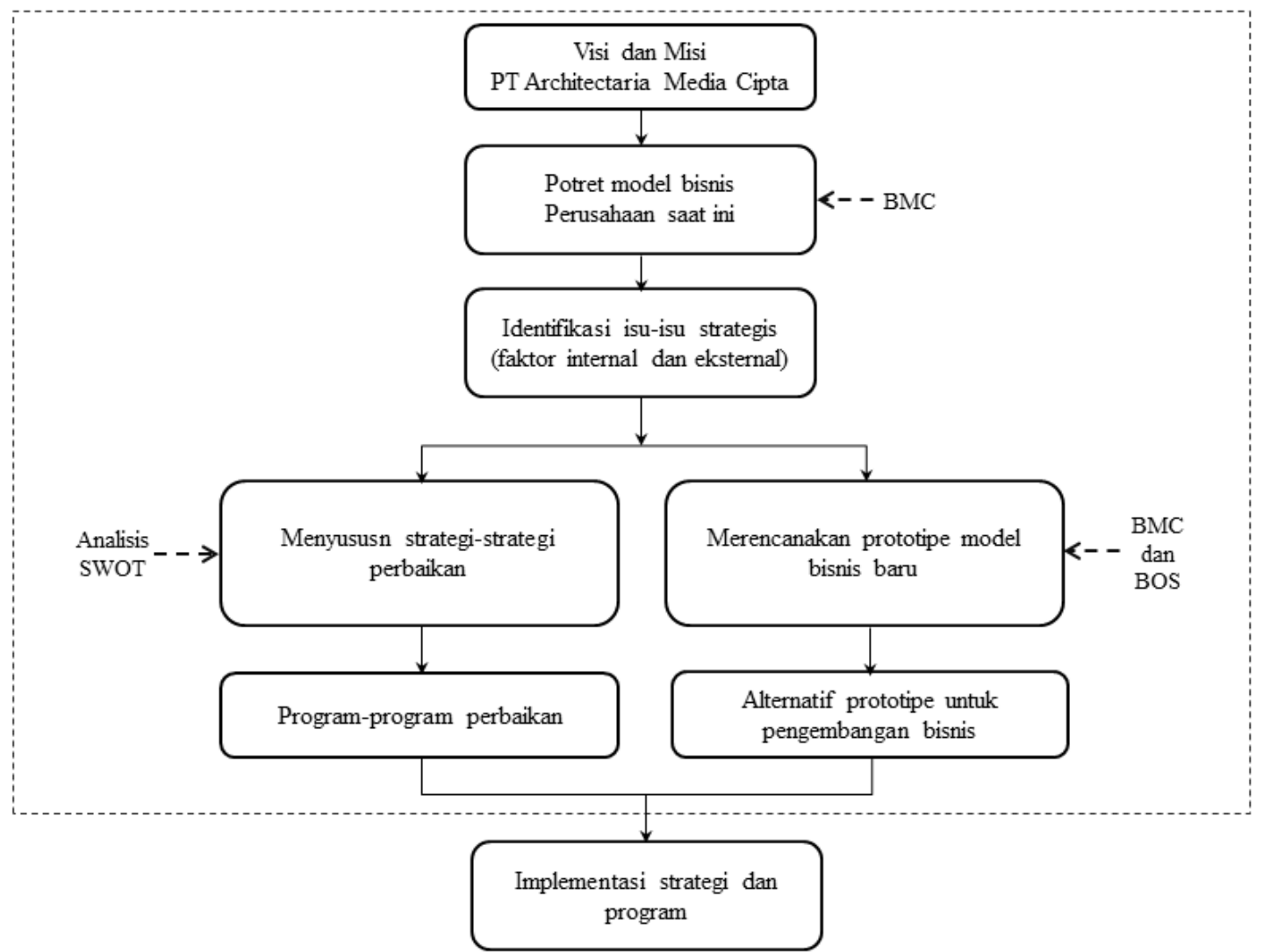

Gambar 1. Kerangka pemikiran konseptual 
Berdasarkan visi dan misi perusahaan, dapat diketahui bahwa PT AMC memfokuskan dirinya untuk menjadi perusahaan penyedia jasa konsultan desain arsitektur, desain interior, penyedia jasa kontraktor yang bermutu, dan mampu menjadi perusahaan berkelas internasional.

\section{Identifikasi Model Bisnis Perusahaan Saat Ini}

Memotret atau memetakan kanvas model bisnis pada PT AMC dilakukan dengan menggunakan metode $\mathrm{BMC}$, yaitu sebuah metode yang dikembangkan oleh Alexander Osterwalder dan Ygves Pigneur (2012). Proses pengambilan data pada penelitian ini melibatkan direktur perusahaan dan para manajer dari berbagai divisi sebagai responden untuk menggambarkan model bisnis yang saat ini sedang dijalankan oleh PT AMC. Pengambilan data dari para responden dilakukan dengan melaksanakan FGD, dimana setiap responden menjawab setiap pertanyaan kuisioner penelitian secara bersama-sama mengenai sembilan unsur kanvas model bisnis PT AMC. Berdasar-kan hasil pemetaan terhadap sembilan elemen BMC, maka gambaran kanvas model bisnis yang saat ini dijalankan oleh PT AMC dapat dilihat pada Gambar 2.

\section{a. Customer Segments}

Komposisi segmen pelanggan dari PT AMC saat ini dapat digambarkan besarnya adalah klien individu atau perseorangan sebesar $60 \%$, klien dari perusahaan swasta sebesar $30 \%$ klien dari perusahaan BUMN sebesar 5\%, dan klien dari institusi dan lembaga-lembaga negara dan pendidikan adalah sebesar $5 \%$.

\section{b. Value Proposition}

Proposisi nilai yang ditawarkan oleh PT AMC kepada pelanggannya adalah (1) kebutuhan untuk mendapatkan jasa desain arsitektur, desain interior yang berkualitas dengan konsep yang matang namun unik; (2) Timeline penyelesaian pekerjaan desain yang dimulai dari penyusunan konsep desain sampai dengan pembuat shop drawing dapat diselesaikan dengan waktu yang lebih cepat; (3) Biaya jasa desain arsitektur, desain interior dan produk turunannya sampai dengan shop drawing dengan biaya yang lebih kompetitif dibandingkan kompetitor; (4) Biaya pelaksana-an pekerjaan konstruksi dan pekerjaan interior yang lebih murah dengan kualitas yang sama baiknya dengan perusahaan kompetitor.

\section{c. Channels}

Tiga fungsi saluran yang dijalankan oleh perusahaan adalah (1) saluran komunikasi memanfaatkan website, blog, dan RSS Feed. (2) Saluran pemasaran offline memanfaatkan iklan koran, brosur, pamflet, sticker. Saluran pemasaran online memanfaatkan website dan blog. (3) Saluran distribusi untuk mendukung kegiatan khususnya produksi barang-barang furniture di pabrik atau workshop PT AMC.

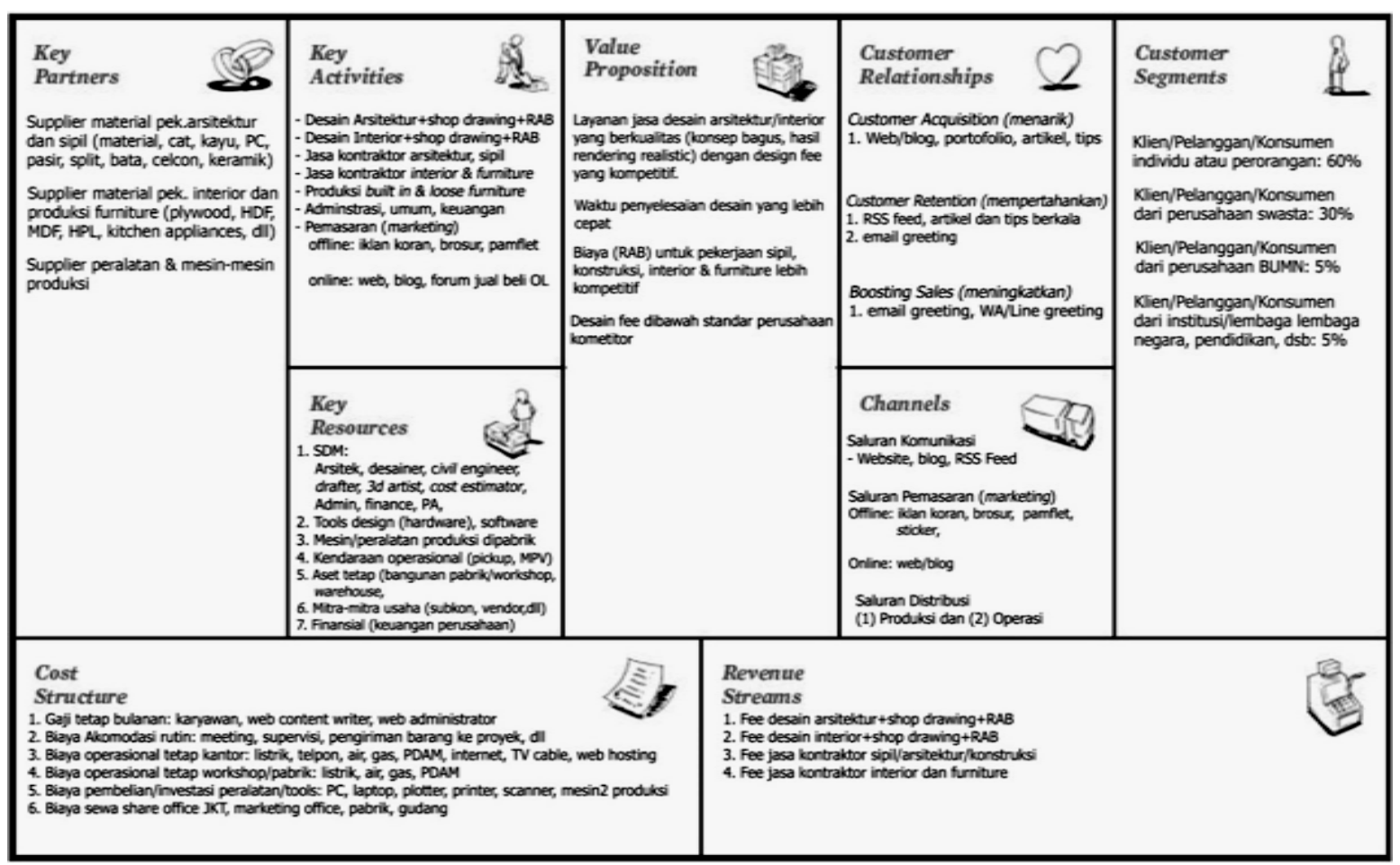

Gambar 2. Kanvas model bisnis PT Architectaria Media Cipta saat ini 


\section{d. Customer Relationship}

Tiga fungsi hubungan pelanggan yang sudah dijalankan oleh PT AMC adalah (1) Customer acquistion atau menarik pelanggan dengan memanfaatkan website, blog, artikel dan tips berkala; (2) Customer retention atau mempertahankan pelanggan dengan RSS feed, artikel dan tips berkala, email greeting; (3) Boosting sales atau meningkatkan penjualan dengan memanfaatkan email greeting atau whatsapp, line greeting.

\section{e. Revenue Streams}

Sumber arus pendapatan bagi model bisnis PT AMC berasal dari empat sumber, yaitu (1) Jasa desain arsitektur lengkap dengan gambar kerja atau shop drawing, dan Rencana Anggaran dan Biaya; (2) Jasa desain interior lengkap dengan gambar kerja atau shop drawing, dan Rencana Anggaran dan Biaya; (3) Fee jasa kontraktor untuk pekerjaan arsitektur, sipil, dan konstruksi umum; (4) Fee jasa kontraktor untuk pekerjaan desain interior dan furniture.

\section{f. Key Resources}

Sumber daya utama yang dimiliki oleh PT AMC dalam menjalankan model bisnisnya adalah (1) Sumber daya manusia, diantara tenaga arsitek, desainer interior, drafter, 3d artist, civil engineer, cost estimator, tenaga admin, finance officer, personal assitance; (2) Tools design, software, hardware, PC, plotter, image scanner, theodolite, waterpass; (3) Mesin-mesin dan peralatan produksi yang ada dipabrik atau workshop; (4) Kendaraan operasional kantor dan pabrik; (5) Aset tetap seperti bangunan kantor, pabrik/workshop, dan gudang; (6) Mitramitra strategis perusahaan termasuk supplier, vendor, sub-kontraktor; (7) Finansial berupa kemampuan keuangan perusahaan.

\section{g. Key Activities}

Aktivitas kunci didalam model bisnis PT AMC adalah (1) Pembuatan desain arsitektur, gambar kerja atau shop drawing, dan pembuatan rencana anggaran dan biaya atau RAB; (2) Pembuatan desain interior, gambar kerja atau shop drawing, dan pembuaran rencana anggaran dan biaya atau RAB; (3) Kegiatan konstruksi bangunan arsitektur, sipil, dan ME; (4) Kegiatan konstruksi atau pelaksanaan pekerjaan desain interior dan furniture; (5) Kegiatan produksi builtin furniture dan loose furniture; (6) Kegiatan operasional kantor, administrasi umum, keuangan; (6) Kegiatan komunikasi dan pemasaran atau marketing and communication secara offline dan online. Komunikasi dan pemasaran offline melalui iklan koran, brosur, dan pamflet. Komunikasi dan pemasaran online melalui website, blog, forum jual beli online.

\section{h. Key Partnership}

Mitra-mitra utama yang dimiliki oleh PT AMC didalam menjalankan model bisnisnya adalah (1) Supplier building material atau vendor untuk pekerjaan arsitektur, dan sipil; (2) Supplier building material atau vendor, home and office appliances, dan kitchen appliances untuk pekerjaan desain interior, dan produksi furniture; (3) Supplier atau vendor untuk design software, hardware, tools, peralatan mekanis, dan mesinmesin produksi.

\section{i. Cost Structures}

Struktur biaya didalam model bisnis PT AMC adalah (1) Gaji tetap bulanan untuk para karyawan; (2) Biaya akomodasi rutin untuk meeting, supervisi ke proyek, pengiriman barang ke proyek; (3) Biaya operasional tetap untuk kantor seperti tagihan listrik, air, gas, PDAM, telpon, majalan dan koran, internet, TV cable, web hosting service; (4) Biaya operasional tetap untuk pabrik atau workshop seperti tagihan listrik, air, gas, dan PDAM; (5) Biaya investasi untuk pembeliaan tools, peralatan mekanis, atau mesinmesin untuk mendukung proses operasional dikantor dan produksi dipabrik; (6) Biaya sewa shared office di Jakarta, marketing office, pabrik dan gudang.

\section{Analisis SWOT Setiap Unsur Business Model Canvas}

Menurut David (2006), analisis SWOT digunakan untuk mengidentifikasi berbagai faktor secara sistematis untuk merumuskan strategi perusahaan. Semua organisasi memili-ki kekuatan dan kelemahan dalam area fungsional bisnis. Tidak ada perusahaan yang sama kuatnya atau lemahnya dalam semua area bisnis. Kekuatan dan kelemahan internal, digabungkan dengan peluang dan ancaman dari eksternal serta pernyataan misi yang jelas, menjadi dasar untuk penetapan tujuan dan strategi. Tujuan dan strategi ditetapkan dengan maksud memanfaatkan kekuatan internal dan mengatasi kelemahan eksternal (David, 2006). Setelah melakukan identifikasi terhadap sembilan unsur BMC yang dijalankan oleh PT AMC saat ini, tahapan selanjutnya adalah melakukan analisis SWOT terhadap sembilan unsur BMC tersebut. 
Analisis SWOT dilakukan dengan tujuan untuk menganalisis kondisi internal dan eksternal yang terjadi pada PT AMC. Hasil dari analisis SWOT ini akan digunakan untuk memperbaiki model bisnis kanvas yang sedang dijalankan oleh
PT AMC. Berdasarkan hasil observasi, wawancara mendalam, dan pengisian kuisioner bersama para responden, maka anlisis SWOT pada sembilan unsur BMC yang saat ini dijalankan oleh PT AMC dapat dilihat pada Tabel 2.

Tabel 2. Analisis SWOT Business Model Canvas PT Architectaria Media Cipta

\begin{tabular}{|c|c|c|c|c|}
\hline Elemen & Kekuatan (S) & Kelemahan (W) & Peluang (O) & Ancaman (T) \\
\hline $\begin{array}{l}\text { Customer } \\
\text { Segments }\end{array}$ & $\begin{array}{l}\text { Perusahaan memiliki } \\
\text { channel atau saluran } \\
\text { (komunikasi dan pema- } \\
\text { saran) untuk menjang- } \\
\text { kau klien atau pelanggan } \\
\text { yang sesuai dengan } \\
\text { segmen pelanggan. }\end{array}$ & $\begin{array}{l}\text { Pelanggan atau calon } \\
\text { pelanggan sering } \\
\text { melakukan price pitching } \\
\text { (membandingkan harga) } \\
\text { yang dihasilkan oleh } \\
\text { perusahaan dengan } \\
\text { produk. }\end{array}$ & $\begin{array}{l}\text { Perusahaan mampu } \\
\text { mendapatkan calon } \\
\text { pelanggan baru atau } \\
\text { mengembangkan produk } \\
\text { yang baru untuk segmen } \\
\text { pasar baru yang terus } \\
\text { tumbuh dan berkembang. }\end{array}$ & $\begin{array}{l}\text { Segmen pelanggan dapat } \\
\text { berkurang apabila } \\
\text { perusahaan pesaing } \\
\text { mampu meningkatkan } \\
\text { kinerja channels, key } \\
\text { resources dan menemukan } \\
\text { value propsition baru. }\end{array}$ \\
\hline $\begin{array}{l}\text { Value } \\
\text { Propisition }\end{array}$ & $\begin{array}{l}\text { Terdapat sinergi atau } \\
\text { hubungan yang kuat } \\
\text { antara produk (produk } \\
\text { barang dan layanan jasa) } \\
\text { yang dihasilkan. }\end{array}$ & $\begin{array}{l}\text { Karena usia perusahaan } \\
\text { masih relatif baru, maka } \\
\text { proposisi nilai belum } \\
\text { memberikan dampak } \\
\text { jaringan yang kuat. }\end{array}$ & $\begin{array}{l}\text { Perusahaan dapat } \\
\text { mengintegrasikan produk } \\
\text { barang dan layanan jasa } \\
\text { (konsultan dan kontraktor) } \\
\text { secara sinergis. }\end{array}$ & $\begin{array}{l}\text { Adanya produk subtitusi } \\
\text { dari berbagai perusahaan } \\
\text { pesaing, terutama } \\
\text { perusahaan yang lebih } \\
\text { dahulu berdiri. }\end{array}$ \\
\hline Channels & $\begin{array}{l}\text { Perusahaan memiliki } \\
\text { saluran (komunikasi dan } \\
\text { pemasaran) untuk } \\
\text { menjangkau pelanggan } \\
\text { dan memberikan manfaat } \\
\text { ekonomis dan } \\
\text { menghasilkan arus } \\
\text { pendapatan. }\end{array}$ & $\begin{array}{l}\text { Saluran yang ada belum } \\
\text { mampu menjangkau } \\
\text { pelanggan baru/ } \\
\text { mempertahankan } \\
\text { pelanggan lama. } \\
\text { Saluran online\&offline } \\
\text { belum terintegrasi } \\
\text { dengan baik. }\end{array}$ & $\begin{array}{l}\text { Perusahaan dapat } \\
\text { meningkatkan jumlah } \\
\text { pelanggan dengan meng- } \\
\text { integrasikan saluran ko- } \\
\text { munikasi dan pemasaran } \\
\text { dengan lebih baik, kedua } \\
\text { saluran bisa diaplikasi kan } \\
\text { secara online dan offline. }\end{array}$ & $\begin{array}{l}\text { Perusahaan pesaing mam- } \\
\text { pu membuat saluran yang } \\
\text { efektif dan terintegrasi, } \\
\text { memanfaatkan saluran } \\
\text { komunikasi dan pemasar- } \\
\text { an online, sehingga mampu } \\
\text { mendapatkan calon klien } \\
\text { lebih banyak. }\end{array}$ \\
\hline $\begin{array}{l}\text { Customer } \\
\text { Relationship }\end{array}$ & $\begin{array}{l}\text { Perusahaan mampu } \\
\text { memanfaatkan dua } \\
\text { saluran utama dengan } \\
\text { baik, sehingga mampu } \\
\text { mendapatkan klien atau } \\
\text { pelanggan baru secara } \\
\text { terus-menerus. }\end{array}$ & $\begin{array}{l}\text { Perusahaan belum } \\
\text { memanfaatkan database } \\
\text { pelanggan atau calon } \\
\text { pelanggan dengan } \\
\text { maksimal untuk } \\
\text { meningkatkan penjualan } \\
\text { produk. }\end{array}$ & $\begin{array}{l}\text { Perusahaan dapat menerap- } \\
\text { kan sistem otomatisasi (email } \\
\text { greeting, push email marketing, } \\
\text { newsletter, RSS feed, dll) } \\
\text { dalam menjaga hubungan } \\
\text { pelanggan dimasa } \\
\text { mendatang }\end{array}$ & $\begin{array}{l}\text { Perusahaan dapat kehi- } \\
\text { langan pelanggan jika tidak } \\
\text { dapat memanfaat-kan } \\
\text { saluran komunikasi dan } \\
\text { pemasaran (web, blog, social } \\
\text { media) untuk men-jaga } \\
\text { hubungan pelanggan }\end{array}$ \\
\hline $\begin{array}{l}\text { Revenue } \\
\text { Stream }\end{array}$ & $\begin{array}{l}\text { Arus pendapatan didalam } \\
\text { model bisnis perusahaan } \\
\text { terdiversivikasi dengan } \\
\text { baik, dan terdiri atas } \\
\text { beberapa sumber yaitu: } \\
\text { jasa desain arsitektur, } \\
\text { desain interior, kontraktor } \\
\text { sipil/arsitektur, dan } \\
\text { kontraktor interior. }\end{array}$ & $\begin{array}{l}\text { Produk layanan jasa dan } \\
\text { barang yang dihasilkan } \\
\text { oleh perusahaan tidak } \\
\text { dalam bentuk jadi, harus } \\
\text { dibuat custom sehingga } \\
\text { jumlah terbatas, dan } \\
\text { harganya relatif mahal, } \\
\text { tidak dapat dijual secara } \\
\text { massal. }\end{array}$ & $\begin{array}{l}\text { Perusahaan dapat } \\
\text { menghasilkan arus } \\
\text { pendapatan berulang } \\
\text { dengan cara menggabung- } \\
\text { kan produk barang dan } \\
\text { jasa (design and built), atau } \\
\text { membuat produk baru } \\
\text { berupa barang yang dapat } \\
\text { dijual secara massal. }\end{array}$ & $\begin{array}{l}\text { Perusahaan pesaing me- } \\
\text { ngembangkan beberapa } \\
\text { sumber arus pendapatan } \\
\text { dari jasa konsultan (arsi- } \\
\text { tektur, interior, civil engi- } \\
\text { neering) dan beberapa arus } \\
\text { pendapatan dari jasa kon- } \\
\text { traktor (sipil, arsitektur, } \\
\text { desain interior, furniture). }\end{array}$ \\
\hline $\begin{array}{l}\text { Key } \\
\text { Resources }\end{array}$ & $\begin{array}{l}\text { Perusahaan memiliki } \\
\text { sendiri sumberdaya utama } \\
\text { SDM (arsitek, deainer } \\
\text { interior, } 3 d \text { artist, engineer, } \\
\text { kepala tukang, dll), tools } \\
\text { (mesin-mesin produksi, } \\
\text { mesin operasional), dan } \\
\text { aset (gudang, } \\
\text { pabrik/workshop). }\end{array}$ & $\begin{array}{l}\text { Belum adanya showroom } \\
\text { yang terintegrasi dengan } \\
\text { pabrik/workshop untuk } \\
\text { memajang mock-up dan } \\
\text { contoh barang hasil } \\
\text { produksi untuk } \\
\text { meyakinkan calon } \\
\text { pelanggan baru apabila } \\
\text { berkunjung. }\end{array}$ & $\begin{array}{l}\text { Perusahaan dapat } \\
\text { meningkatkan arus } \\
\text { pendapatan bagi model } \\
\text { bisnis dengan cara } \\
\text { menambah SDM khusus } \\
\text { menangani kegiatan } \\
\text { pemasaran secara online dan } \\
\text { penjualan secara massal } \\
\text { melalui toko online/webstore. }\end{array}$ & $\begin{array}{l}\text { Penggunaan sumber daya } \\
\text { yang kurang efektif dan } \\
\text { efisien akan menurunkan } \\
\text { produktivitas kerja, } \\
\text { meningkatkan struktur } \\
\text { biaya, sehingga produk } \\
\text { (layanan jasa dan barang) } \\
\text { yang dihasilkan kurang } \\
\text { kompetitif. }\end{array}$ \\
\hline $\begin{array}{l}\text { Key } \\
\text { Activities }\end{array}$ & $\begin{array}{l}\text { Dalam hal teknis, } \\
\text { perusahaan mampu } \\
\text { mengerjakan proses desain } \\
\text { sampai output design } \\
\text { (gambar shop drawing) }\end{array}$ & $\begin{array}{l}\text { Perusahaan belum } \\
\text { memasksimalkan } \\
\text { kegiatan marketing secara } \\
\text { online sebagai aktivitas } \\
\text { utama. Seharusnya } \\
\end{array}$ & $\begin{array}{l}\text { Perusahaan harus } \\
\text { memanfaatkan fasilitas IT } \\
\text { dan teknologi digital untuk } \\
\text { meningkatkan efisiensi kerja } \\
\text { dalam model bisnisnya. }\end{array}$ & $\begin{array}{l}\text { Tim desainer dan teknis } \\
\text { (estimator) tidak mampu } \\
\text { menyusun RAB dengan } \\
\text { waktu yang lebih cepat } \\
\text { dan akurat. Tim marketing }\end{array}$ \\
\hline
\end{tabular}


Lanjutan Tabel 2.

\begin{tabular}{|c|c|c|c|c|}
\hline Elemen & Kekuatan (S) & Kelemahan (W) & Peluang (O) & Ancaman (T) \\
\hline & $\begin{array}{l}\text { dengan lebih cepat. Dalam } \\
\text { hal non-teknis, kegiatan } \\
\text { operasional kantor, } \\
\text { workshop/pabrik sesuai } \\
\text { dengan rencana kegiatan } \\
\text { yang telah disusun tiap } \\
\text { divisi. }\end{array}$ & $\begin{array}{l}\text { kegiatan marketing online } \\
\text { ini ditambah porsinya, } \\
\text { terutama push email } \\
\text { marketing system untuk } \\
\text { menjangkau pelanggan } \\
\text { korporat dan social media } \\
\text { marketing untuk } \\
\text { pelanggan individu. }\end{array}$ & $\begin{array}{l}\text { Misal pemanfaatan website, } \\
\text { blog, social media FP, online } \\
\text { marketing, push email } \\
\text { marketing akan } \\
\text { meningkatkan efisiensi } \\
\text { dan keuntungan bagi } \\
\text { perusahaan. }\end{array}$ & $\begin{array}{l}\text { yang belum optimal } \\
\text { dalam mendapatkan } \\
\text { calon pelanggan baru } \\
\text { yang prospektif atau } \\
\text { potensial untuk } \\
\text { menghasilkan arus } \\
\text { pendapatan bagi model } \\
\text { bisnis dimasa mendatang. }\end{array}$ \\
\hline $\begin{array}{l}\text { Key } \\
\text { Partnership }\end{array}$ & $\begin{array}{l}\text { Perusahan menjalin hubu- } \\
\text { ngan baik dan menjalani } \\
\text { kerja sama strategis dan } \\
\text { menguntungkan dengan } \\
\text { mitra-mitra utama. Mitra } \\
\text { mitra perusahaan mem- } \\
\text { bantu untuk menyele- } \\
\text { saikan berbagai proyek, } \\
\text { sehingga hasil yang } \\
\text { dicapai lebih baik. }\end{array}$ & $\begin{array}{l}\text { Bekerjasama dengan } \\
\text { beberapa mitra didalam } \\
\text { menyelesaikan proyek } \\
\text { akan menyebabkan } \\
\text { peningkatan struktur } \\
\text { biaya, sehingga produk } \\
\text { yang dihasilkan oleh } \\
\text { perusahaan akan } \\
\text { menjadi lebih mahal. }\end{array}$ & $\begin{array}{l}\text { Perusahaan dapat } \\
\text { melakukan kerjasama dalam } \\
\text { bentuk kolaborasi yang lebih } \\
\text { kuat dengan mitra-mitra } \\
\text { utama (supplier, vendor, sub- } \\
\text { kontrak tor, hosting service, } \\
\text { outsourcing service), sehingga } \\
\text { perusahaan dapat lebih } \\
\text { fokus pada bisnis inti } \\
\text { (utama) perusahaan. }\end{array}$ & $\begin{array}{l}\text { Pelanggan atau konsumen } \\
\text { dapat merasa kurang puas } \\
\text { dengan kinerja dari mitra- } \\
\text { mitra usaha yang menjadi } \\
\text { rekanan perusahaan } \\
\text { dalam melaksanakan } \\
\text { proyek terutama layanan } \\
\text { after sales nya. Perlu } \\
\text { jaminan retensi atau } \\
\text { garansi pekerjaan dari } \\
\text { mitra usaha. }\end{array}$ \\
\hline $\begin{array}{l}\text { Cost } \\
\text { Structures }\end{array}$ & $\begin{array}{l}\text { Harga jual produk, } \\
\text { besaran fee atas layanan } \\
\text { jasa dari perusahaan } \\
\text { dapat diprediksi dengan } \\
\text { baik. Perusahaan juga } \\
\text { mendapat keuntungan } \\
\text { dari skala ekonomi } \\
\text { (economic of scale). }\end{array}$ & $\begin{array}{l}\text { Kegiatan produksi dan } \\
\text { operasional didalam } \\
\text { model bisnis perusahaan } \\
\text { masih padat modal, } \\
\text { khususnya proyek } \\
\text { konstruksi, desain } \\
\text { interior, dan produksi } \\
\text { furniture kurang efisien } \\
\text { dalam penggunaan biaya }\end{array}$ & $\begin{array}{l}\text { Perusahaan dapat } \\
\text { menambah jumlah mesin- } \\
\text { mesin produksi dan } \\
\text { tools/peralatan mekanis } \\
\text { lainnya untuk mempercepat } \\
\text { proses produksi (konstruksi, } \\
\text { produksi furniture), sehingga } \\
\text { struktur biaya dan harga jual } \\
\text { dapat lebih murah. }\end{array}$ & $\begin{array}{l}\text { Jika perusahaan pesaing } \\
\text { dapat bekerja lebih cepat } \\
\text { dan metode kerja yang } \\
\text { efektif sehingga mampu } \\
\text { memberikan harga } \\
\text { layanan dan produk yang } \\
\text { lebih murah } \\
\text { dibandingkan yang } \\
\text { ditawarkan oleh PT } \\
\text { Architectaria Media Cipta. }\end{array}$ \\
\hline
\end{tabular}

Berdasarkan hasil analisis SWOT pada Tabel 2, secara umum dikelompokkan menjadi dua lingkungan utama, yaitu (1) Analisis lingkungan internal berupa kekuatan dan kelemahan; (2) Analisis lingkungan eksternal berupa peluang dan ancaman. Selanjutnya tujuan perusahaan, model bisnis, dan strategi bisnis ditetapkan dengan memanfaatkan kekuatan internal dan mengatasi kelemahan eksternal (Handayani, 2009).

Analisis lingkungan internal dan eksternal perusahaan digabungkan dengan pernyataan visi dan misi dari PT AMC, menjadi dasar untuk penetapan tujuan perusahaan, penyusunan model bisnis perbaikan, prototipe model bisnis baru, dan strategi untuk mendukung model bisnis (perbaikan dan prototipe) perusahaan dimasa mendatang.

\section{Perbaikan Model Bisnis PT AMC}

Perbaikan model bisnis sangat penting bagi keberhasilan perusahaan yang memungkinkan perusahaan yang memungkinkan perusahaan untuk dapat beradaptasi dengan perubahanperubahan di pasar maupun lingkungan usaha yang semakin kompetitif. Selain itu, perbaikan model bisnis juga dapat meningkatkan dan membangun organisasi internal perusahaan (Casadesus dan Ricart, 2010). Upaya pengembangan organisasi dapat dilakukan dengan melakukan perbaikan pada unsur-unsur yang menjadi kelemahan didalam organisasi atau perusahaan. Kondisi ini membuat perusahaan harus mengembangkan sumber daya, aset, SDM yang dimilkinya menjadi lebih baik, sehingga dapat bertahan dalam menghadapi perubahan dan persaingan.

Perbaikan model bisnis kanvas yang dijalankan oleh perusahaan dilakukan dengan melakukan identifikasi pada sembilan unsur BMC menggunakan analisis SWOT yang dilakukan dengan cara FGD, sehingga diperoleh model bisnis yang baru (Hindarwati dan Arifin, 2015). Hasil analisis SWOT terhadap sembilan unsur BMC PT AMC ditunjukkan pada Gambar 3.

\section{Prototipe Model Bisnis Baru PT AMC}

Didalam membuat prototipe model bisnis baru yang inovatif, menciptakan ide adalah bagian paling mendasar dan terpenting yang harus dilakukan oleh perusahaan (Dewobroto, 2012). Model bisnis baru yang inovatif dengan 
berfokus untuk memfasilitasi dan mendukung pergeseran atau perubahan dengan berfokus pada produk maupun perspektif layanan, sehingga didalam model bisnis yang inovatif sangat memperhitungkan pendekatan sistem produkpelayanan yang terpadu (Gassmann et al., 2016). Beberapa hasil studi menyatakan bahwa model bisnis yang inovatif harus mampu menyelaraskan kemam-puan internal atau beradaptasi dengan perubahan eksternal, seperti perkembangan teknologi (Chesbrough, 2010) atau mengubah nilai-nilai pelanggan (Mc Grath, 2010). Ide untuk menciptakan inovasi bisnis dapat diperoleh dari berbagai sumber dan sembilan unsur yang ada didalam BMC dapat dijadikan titik awal untuk melakukan perubahan dan membuat inovasi bisnis. Masing-masing unsur tersebut dapat memberikan dampak yang kuat dan memengaruhi kedelapan unsur lainnya (Gondosaputro, 2017).

Hasil identifikasi terhadap model bisnis kanvas yang dijalankan oleh perusahaan dan model bisnis kanvas perbaikan tersebut dapat dikombinasikan dengan prinsip dasar Blue Ocean Strategy (Djap, 2016). Tujuannya untuk menggambarkan unsur mana yang perlu untuk mendapat perlakuan kerangka kerja empat tindakan (menciptakan, mengeliminasi, meningkatkan, dan mengurangi). Titik awal perubahan tersebut dapat ditentukan dengan melihat seberapa besar pengaruh salah satu unsur terhadap unsur lainnya. Berdasarkan hasil analisis SWOT dan brainstorming saat melakukan FGD dengan pihak manajemen PT AMC, maka dirancang satu prototipe model bisnis baru yang akan dijalankan oleh perusahaan dimasa mendatang.

Prototipe model bisnis baru dirancang berdasarkan hasil kombinasi antara (1) BMC yang saat ini dijalankan oleh perusahaan, (2) BMC perbaikan, serta (3) Kerangka kerja empat tindakan. Konsep kerangka kerja empat tindakan sendiri merupakan bagian dari Blue Ocean Strategy (BOS) yang berpusat pada penawaran untuk menciptakan value proposition yang baru bagi pelanggan (Hadihardjaja, 2005). Prototipe model bisnis baru PT AMC ditunjukkan pada Gambar 4.

Pada prototipe model bisnis yang baru PT AMC tidak memerlukan biaya untuk pengembangan fasilitas, infrastruktur, pembelian peralatan mekanis, mesin-mesin yang terlalu tinggi. Proses produksi loose furniture dengan dimensi yang fixed dan compact dapat dilakukan dipabrik atau workshop yang telah dimiliki perusahaan saat ini. Peralatan dan mesin-mesin pun telah ada, jika permintaannya besar dan kapasitas produksi harus ditingkatkan, maka perusahaan cukup menambah peralatan dan mesin-mesin yang sudah ada menjadi lebih banyak. Untuk kegiatan pemasaran dan penjualan,

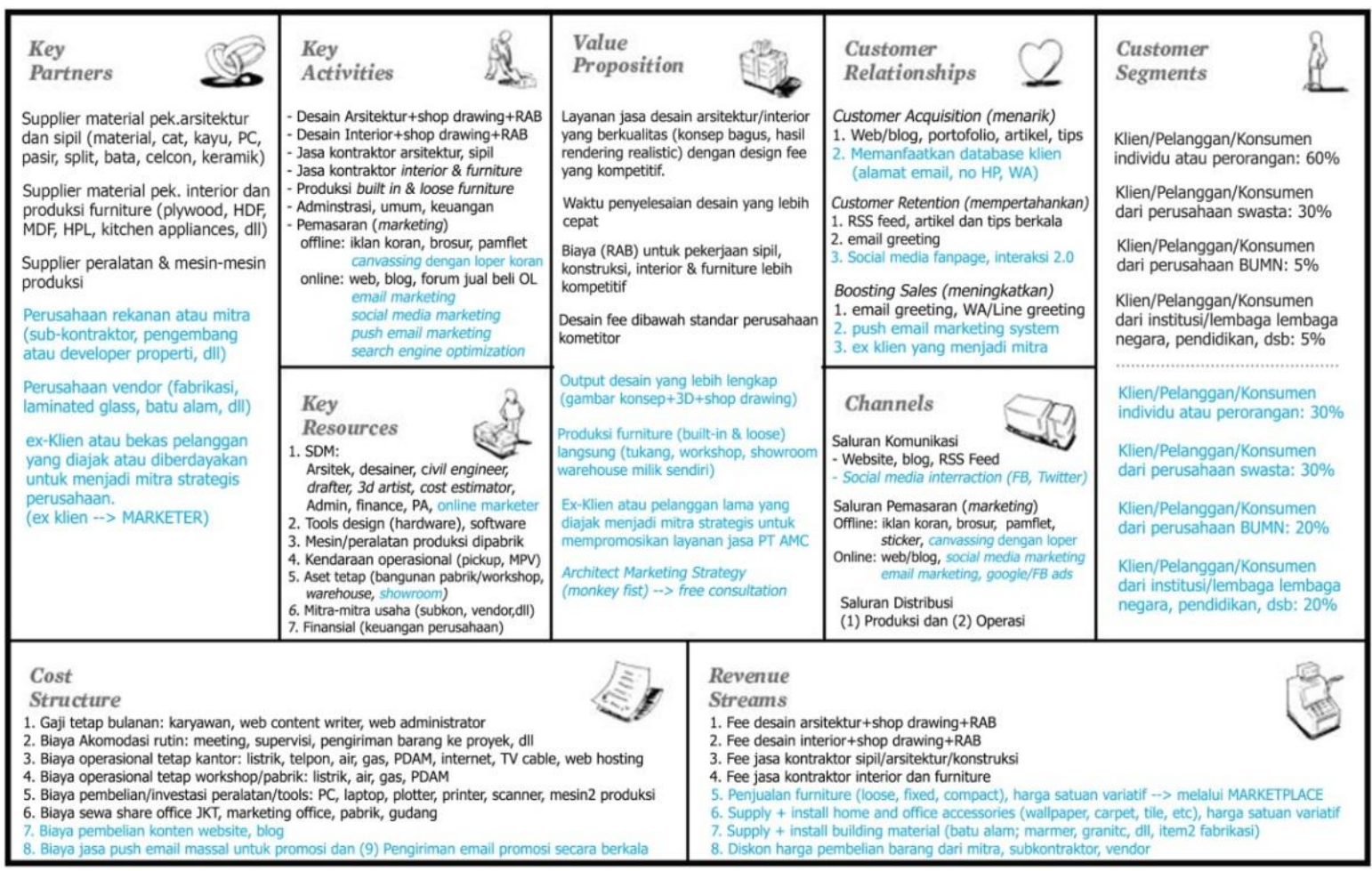

Gambar 3. Kanvas model bisnis perbaikan PT AMC 


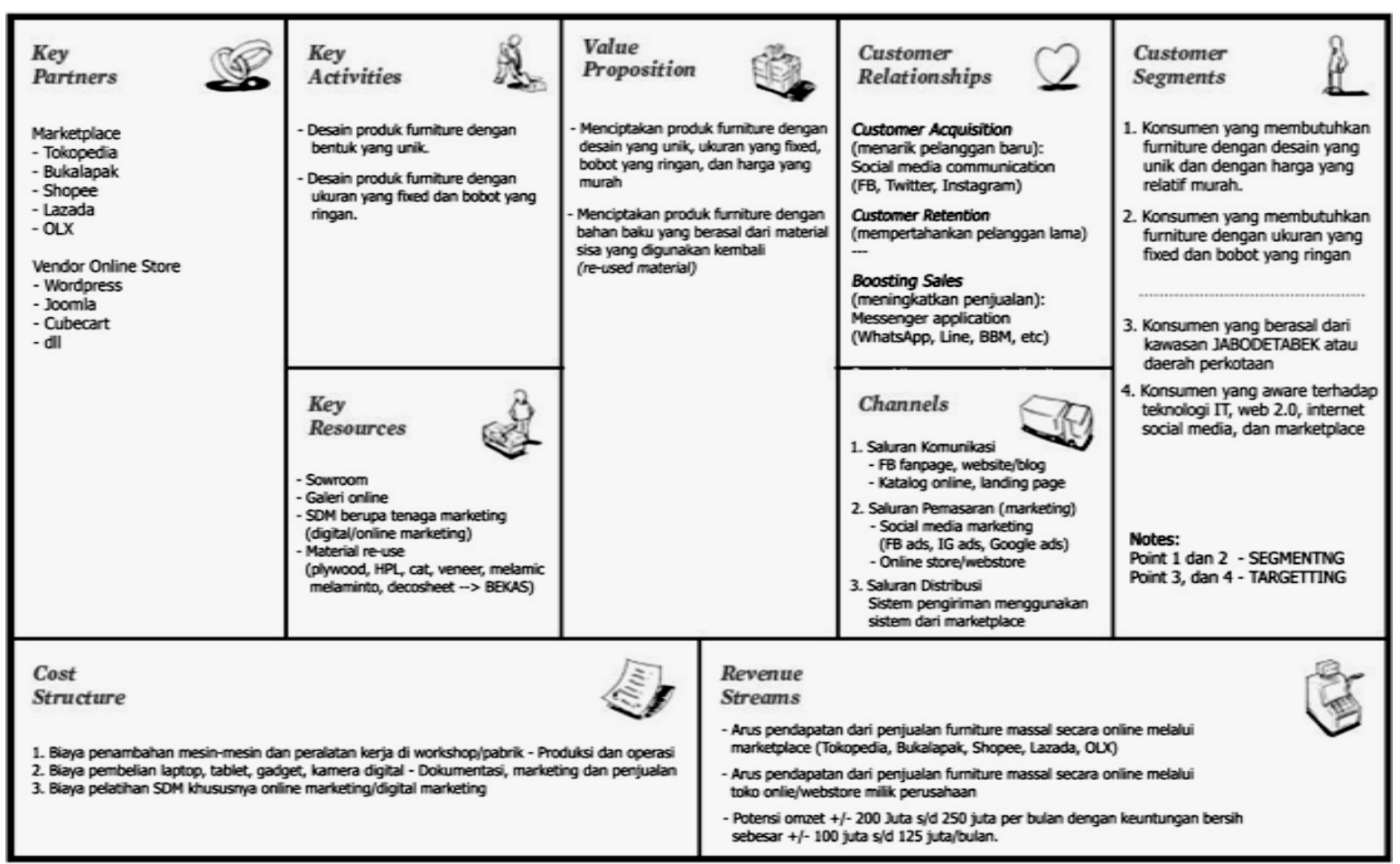

Gambar 4. Kanvas model bisnis prototipe PT AMC

perusahaan hanya perlu membeli kamera digital, gadget berupa laptop atau tablet dengan sistem operasi windows mobile, android atau IOS. Gadget tersebut dapat dimanfaatkan untuk memfoto, mengedit dan menyimpan foto-foto produk furniture yang akan dijual. Gadget tersebut juga dapat dimanfaatkan untuk mengunduh aplikasi marketplace untuk melakukan penjual-an produk, dan dapat juga digunakan untuk browsing webstore/online store untuk melakukan penjualan di toko online milik perusahaan. Alternatif prototipe model bisnis baru ini dapat menimbulkan biaya baru bagi perusahaan, namun biaya tambahan tersebut bukanlah fixed cost yang rutin dikeluarkan oleh perusahaan setiap bulan. Biaya-biaya tambahan tersebut diantaranya biaya pelatihan SDM dibidang marketing khususnya digital marketing, sosial media marketing atau online marketing, biaya promosi, dan biaya investasi pembelian gadget atau kamera digital.

\section{Implikasi Manajerial}

Berdasarkan hasil perbaikan sembilan unsur BMC dan pembuatan prototipe model bisnis baru, beberapa hal penting yang menjadi kunci keberlangsungan model bisnis PT AMC dimasa mendatang.
1. PT AMC harus merubah komposisi segmen pelanggan atau calon klien nya untuk meningkatkan potensi keuntungan dan arus pendapatan bagi model bisnis perusahaan dimasa mendatang.

2. PT Architectaria Media Cipta dapat lebih meningkatkan kinerja dan efektivitas salur-an utama khususnya saluran komunikasi dan pemasaran dengan mengintegrasikan media online dan offline.

3. Tiga fungsi customer relationship yang harus dijalankan oleh perusahaan adalah (1) Customer acquisition dengan memanfaatkan database klien (email, nomor telpon atau handphone); (2) Customer retention dengan memanfaatkan social media fanpage, selanjutnya perusahaan perlu secara aktif melakukan interaksi dua arah dengan pelanggannya; (3) Boasting sales dengan memanfaatkan push email marketing system.

4. PT AMC dapat mengembangkan arus pendapatan bagi model bisnis perusahaan dimasa mendatang dengan menambahkan atau menggabungkan beberapa produk (layanan jasa dan barang-barang hasil produksi).

5. Dengan tujuan meningkatkan kinerja sumber daya utama, PT AMC perlu menambahkan SDM yang khusus menangani kegiatan marketing and communication secara online, dan 
social media officer untuk menarik calon pelanggan baru dimasa mendatang. Sumber daya lainnya yang dianggap paling penting untuk ditambah dimasa mendatang adalah fasilitas showroom yang menyatu dengan pabrik atau workshop.

6. Aktivitas kunci yang harus ditambahkan didalam model bisnis perusahaan dimasa mendatang adalah; (1) Kegiatan pemasaran offline. (2) Kegiatan pemasaran online yang memaksimalkan promosi melalui sosial media (social media marketing). Perusahaan dapat memanfaatkan fasilitas iklan berbayar untuk meningkatkan prosentase penjualan produk yang dihasilkan oleh perusahaan.

7. Dalam hal kemitraan strategis, PT AMC perlu untuk bekerja sama dengan dua mitra utama, yaitu (1) Perusahaan properti atau pengembang perumahan dan (2) pelanggan lama atau klien untuk dijadikan broker atau mediator.

8. Dengan tujuan meningkatkan efisiensi model bisnis dari PT AMC dimasa mendatang, perusahaan perlu mengurangi kegiatan produksi dan operasional yang bersifat padat modal. Menambah jumlah peralatan mekanis, dan memperbesar porsi pemasaran berbasis online akan efektif untuk mengurangi struktur biaya didalam model bisnis perusahaan.

9. Dengan tujuan meningkatkan efisiensi model bisnis dari PT AMC dimasa mendatang, perusahaan perlu mengurangi kegiatan produksi dan operasional yang bersifat padat modal. Menambah jumlah peralatan mekanis, dan memperbesar porsi pemasaran berbasis online akan efektif untuk mengurangi struktur biaya didalam model bisnis perusahaan.

\section{KESIMPULAN}

1. PT AMC memiliki beberapa kendala didalam menjalankan model bisnisnya saat ini, yaitu: (1) Design fee, contractor fee dan output yang sama dengan perusahaan pesaing; (2) Komposisi segmen pelanggan dengan komposisi klien individu yang lebih besar; (3) Belum menjalankan tiga aktivitas utama untuk menjaga hubungan pelanggan; (4) Belum menjalankan saluran komunikasi dan pemasaran yang seimbang.

2. Hasil analisis SWOT pada unsur BMC menunjukkan bahwa terdapat faktor internal dan eksternal yang menjadi kekuatan dan kelemahan bagi perusahaan dalam menjalankan model bisnisnya. Ada tujuh unsur yang harus diperbaiki secara major dan dua unsur diperbaiki secara minor.

3. PT AMC perlu melakukan perbaikan pada sembilan unsur model bisnis perusahaan dimasa mendatang, yaitu: (1) memberikan proposisi nilai baru berupa service fee yang lebih murah namun dengan output dan mutu lebih baik dibanding pesaing; (2) efektivitas kerja sumber daya utama khususnya SDM, efisiensi penggunaan sumber daya utama lainnya berupa aset, dan modal; (3) peningkatan kinerja saluran komunikasi dan pemasaran melalui media digital, media online dan sosial media; (4) memperluas cakupan segmen pelanggan baru khususnya kelas menengahatas pengguna internet dan sosial media; (5) Menambah aktivitias kunci dengan melakukan kegiatan pemasaran berbasis online dan aktif memanfaatkan database pelanggan; (6) Menjaga dan meningkatkan hubungan yang baik dengan pelanggan khususnya pelanggan lama untuk meningkatkan kemungkinan terjadinya transaksi berulang dimasa mendatang; (7) Menambah sumber arus pendapatan baru dengan menggabungkan layanan jasa dan penciptaan produk baru; (8) Kerja sama strategis dengan berbagai mitra utama untuk mendapatkan keuntungan bersama; (9) Menurunkan struktur biaya dengan menambah penggunaan mesin-mesin serta peralatan mekanis.

4. Prototipe model bisnis baru dibuat dengan proposisi nilai baru yaitu membuat produk home $\mathcal{E}$ office furnishings dengan desain yang unik, ukuran yang fixed, bobot yang ringan sehingga dapat dijual secara massal melalui webstore dan marketplace. Produk inovatif dibuat dengan memanfaatkan material sisa dengan konsep re-use dan re-cycle, sehingga harga jual produk tetap murah.

\section{DAFTAR PUSTAKA}

[BPS] Badan Pusat Statistik. 2016. Ringkasan Statistik Konstruksi Tahun 2010-2015. [internet], [diunduh 17 Januari 2017]. Tersedia pada: https://www.bps.go.id/ linkTableDinamis/view/id/912

Casadesus, R., J.E. Ricart. 2010. From Strategi to Business Models and Onto Tactics. Long Range Planning. 43(2010): 195-215. 
Chesbrough, H. 2010. Business Model Innovation: Opportunities And Barriers. Long Range Planning. 43(2-3): 354-363.

David, F.R. 2006. Management Strategis Edisi ke-7. Jakarta (ID): PT.Prehallindo.

Dewobroto, W.S. 2012. Penggunaan Business Model Canvas Sebagai Dasar untuk Menciptakan Alternatif Strategi Bisnis Dan Kelayakan Usaha. Jurnal Teknik Industri. 12(4): 11-40.

Djap, K. 2016. Evaluasi dan Perancangan Model Bisnis Pada PT Sarana Warna Megah.Agora. 4(1): 98-107.

Gunawan, A.A., R. Indriyani. 2014. Evaluasi Strategi Bersaing Pada PT Green Dewata Di Denpasar, Bali. Agora. 2(1): 1-16.

Gassmann, O., K. Frankenberger, M. Csik. 2016. Business Model Navigator-55 Model Bisnis Unggulan yang Akan Mengubah Bisnis Anda. Jakarta (ID): PT. Gramedia Pustaka Utama.

Gondosaputro, H.M. 2017. Analisis Business Model Canvas Pada CV Triputra Perkasa. Agora. 5(1): 1-7.

Gunawan, A.A., R. Indriyani. 2014. Evaluasi Strategi Bersaing Pada PT Green Dewata Di Denpasar, Bali. Agora. 2(1): 1-16.
Hadihardjaja, J. 2005. Membangun Industri Konstruksi Indonesia Menjadi Kelas Dunia. Media Komunikasi Teknik Sipil. 13(2): 11-19.

Halim, A.G.S., R.H. Mustamu. 2013. Analisis Deskriptif Strategi Bersaing pada Perusahaan Kontraktor Penyedia Kebutuhan Konstruksi. Agora. 1(1): 1-15.

Handayani, F.S. 2009. Manajemen Strategi Perusahaan Konsultan Golongan Kecil Dalam Menghadapi Era Kebebasan Investasi. Media Teknik Sipil. 9(2): 100-106.

Hindarwati, E.N., S.B. Arifin. 2015. Penerapan Strategi Bisnis pada Perusahaan Kontraktor Tiang Pancang di Indonesia. Jurnal Manejemen Indonesia. 15(3): 243-252.

McGrath, R.G. 2010. Busines Models: A Discovery Driven Approach. Long Range Planning. 43(1): 247-261.

Osterwalder, A., Y. Pigneur. 2012. Business Model Generation. Jakarta (ID): PT. Elex Media Komputindo.

Porter, M.E. 1992. Strategi Bersaing-Teknik Menganalisis Industri dan Pesaing. Jakarta (ID): Penerbit ERLANGGA. 